Original Article

\title{
Assessment of particulate matter (PM) in ambient air of different settings and its associated health risk in Haripur city, Pakistan
}

\author{
Avaliação de material particulado (MP) no ar ambiente de diferentes configurações e \\ sua associação com o risco à saúde na cidade de Haripur, Paquistão
}

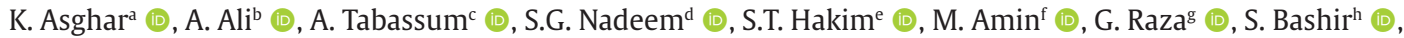 \\ N. Afshand (D), N. Usmani (D), N. Aurangzeb (D), A. Naz ${ }^{\text {a }}$ (D) and M. Hussaini* (D) \\ aUniversity of Haripur, Department of Environmental Sciences, Hattar Road, Haripur city KP, Pakistan \\ ${ }^{\mathrm{b}}$ Karakoram International University, Department of Forestry, Range and Wildlife Management, Gilgit-Baltistan, Pakistan \\ 'The Islamia University of Bahawalpur, Department of Commerce, Punjab, Pakistan \\ JJinnah University for Women, Department of Zoology, Nazimabad, Karachi, Sindh, Pakistan \\ eDine College, School of STEM, Tuba City, Arizona, USA \\ fShaheed Benazir Bhutto University, Department of Environmental Sciences, Sheringal, Dir (U), KP, Pakistan \\ gUniversity of Baltistan, Department of Biological Sciences, Skardu, Gilgit-Baltistan, Pakistan \\ hPlanning, Agriculture Research System, Peshawar, Khyber Pakhtunkhwa, Pakistan \\ iUniversity of Haripur, Department of Forestry and Wildlife Management, Hattar Road, Haripur City, KP, Pakistan
}

\begin{abstract}
Particulate matter (PM) is a major air pollutant causing serious health problems. The aim of the present study was to find out concentration of PM in ambient air and its associated health risk in Haripur city, Pakistan. Twentythree samples were taken at various educational institutes, hospitals, recreational areas and industries in Haripur city. Concentration of $\mathrm{PM}_{2.5}\left(\mu \mathrm{g} / \mathrm{m}^{3}\right)$ and $\mathrm{PM}_{10}\left(\mu \mathrm{g} / \mathrm{m}^{3}\right)$ was measured with Youngteng YT-HPC 3000A portable PM counter. The results revealed that values of both $\mathrm{PM}_{2.5}$ and $\mathrm{PM}_{10}$ were above the permissible limits $\left(35 \mu \mathrm{g} / \mathrm{m}^{3}\right.$ for $\mathrm{PM}_{2.5}$ and $150 \mu \mathrm{g} / \mathrm{m}^{3}$ for $\mathrm{PM}_{10}$ ) set by Environmental Protection Agency Pakistan (Pak-EPA) in all the educational institutes, hospitals, recreational areas and industries investigated. Furthermore, significant $(\mathrm{p}<0.05)$ variation was found in the concentration of both $\mathrm{PM}_{2.5}$ and $\mathrm{PM}_{10}$ in all the educational institutes, hospitals, recreational areas, and industries studied. The concentration of $\mathrm{PM}_{2.5}$ was positively correlated with the concentration of $\mathrm{PM}_{10}$ in all the sampling sites. Therefore, from 1-14 scale standard of health index, the values of $\mathrm{PM}_{2.5}$ and $\mathrm{PM}_{10}$ exhibited that the ambient air quality of Haripur city Pakistan is under high risk. If the regulatory authorities such as Environmental Protection Agency, Health Department and Local Government monitor PM pollution in different settings of Haripur city, then a decrease can be possible in the pollution level. The remedies that can be taken to overcome the problem of ambient air pollution such as PM are plantation of trees at the sites where there are higher levels of air pollutants and use of masks on personal protection basis along with implementation of pollution control system in industries of Hattar Industrial Estate Haripur city, Pakistan.
\end{abstract}

Keywords: particulate matter, Air quality index, health impacts, air pollutants, Haripur.

\begin{abstract}
Resumo
O material particulado (MP) é um importante poluente do ar que causa sérios problemas de saúde. O objetivo do presente estudo foi descobrir a concentração de MP no ar ambiente e sua associação com o risco à saúde na cidade de Haripur, Paquistão. Vinte e três amostras foram coletadas em várias instituições de ensino, hospitais, áreas recreativas e indústrias na cidade de Haripur. A concentração de $\mathrm{MP}_{2,5}\left(\mu \mathrm{g} / \mathrm{m}^{3}\right)$ e $\mathrm{MP}_{10}\left(\mu \mathrm{g} / \mathrm{m}^{3}\right)$ foi medida por meio do contador de MP portátil Youngteng YT-HPC 3000A. Os resultados revelaram que os valores de $\mathrm{MP}_{2,5} \mathrm{e}$ $\mathrm{MP}_{10}$ estavam acima dos limites permitidos $\left(35 \mu \mathrm{g} / \mathrm{m}^{3}\right.$ para $\mathrm{MP}_{2,5}$ e $150 \mu \mathrm{g} / \mathrm{m}^{3}$ para $\mathrm{MP}_{10}$ ) estabelecidos pela Agência de Proteção Ambiental do Paquistão (Pak-EPA) em todas as instituições de ensino, hospitais, áreas recreativas e indústrias investigadas. Além disso, foi encontrada variação significativa $(\mathrm{p}<0,05)$ na concentração de $\mathrm{MP}_{2,5} \mathrm{e}$ $\mathrm{MP}_{10}$ em todos os locais estudados. A concentração de $\mathrm{MP}_{2,5}$ correlacionou-se positivamente com a concentração de $\mathrm{MP}_{10}$ em todos os locais de amostragem. Portanto, a partir da escala padrão 1-14 do índice de saúde, os valores de $\mathrm{MP}_{2,5}$ e $\mathrm{MP}_{10}$ mostraram que a qualidade do ar ambiente na cidade de Haripur, Paquistão, está sob alto risco. Se
\end{abstract}

*e-mail: majid@uoh.edu.pk

Received: September 9, 21 - Accepted: January 14, 22

This is an Open Access article distributed under the terms of the Creative Commons Attribution License, which permits unrestricted use, distribution, and reproduction in any medium, provided the original work is properly cited. 
as autoridades reguladoras, como a Pak-EPA, o Departamento de Saúde e o governo local, monitorarem a poluição por MP em diferentes configurações da cidade de Haripur, pode ser que haja uma diminuição no nível de poluição. As medidas que podem ser tomadas para superar o problema da poluição do ar ambiente, como o MP, são o plantio de árvores nos locais onde há maiores níveis de poluentes atmosféricos, o uso de máscaras e a implantação de sistema de controle de poluição nas propriedades industriais de Hattar, na cidade Haripur, Paquistão.

Palavras-chave: material particulado, Índice de qualidade do ar, impactos na saúde, poluentes do ar, Haripur.

\section{Introduction}

Ambient air quality is one of the main elements to check pollution level in the environment. Transportation, residential, recreational, educational and industrial facilities are the major sources creating air pollution (Abali et al., 2018; Aziz et al., 2015a). Good ambient air quality is a pre-requisite for healthy lives and life styles. Fast rate of industrialization has been causing higher emissions of many gases and particulate matter (PM) (Cesaroni et al., 2014). These pollutants are the primary pollutants and transformed into secondary pollutants through chemical reactions. Ambient air pollution (AAP) is the global issue concerned to human health. All the non- $\mathrm{CO}_{2}$ emissions are the climate-alerting pollutants that caused severe health impacts declared by IPCC and many other organizations (Stafoggia et al., 2014). The health impacts are either direct or indirect in urban areas (Akinfolarin et al., 2017; Alam et al., 2015; Ali et al., 2015). PM can stay in the atmosphere for few seconds or it can remain suspended for years. Large size particle spent less time in suspended state for few seconds, on the other hand small size particle remains suspended for years (Pokhrel et al., 2015). PM also influences perceivability in megacities (urban areas having population more than 10 million). PM can cause cardiopulmonary illness, lung disease, newborn child mortality or older mortality. The impacts of fine particles are higher than that of bigger ones (Araujo et al., 2014). Repetitive respiratory hypersensitivity can be caused by PM as they can achieve the most profound opening of the lungs without troubling and hurting (Nagar et al., 2014). The PM causes disturbance in mucous layer and upper respiratory tract and cause neuropsychological impacts (Habil et al., 2013; Nagar et al., 2014). PM cause various diseases such as perpetual bronchitis, lungs disturbance, asthma, incessant hack, rhinitis, mucus generation, exhaustion, migraine, lung malignant growth, hypersensitivity, sudden passing and diminished protection from respiratory contamination, distinctive aspiratory sicknesses, for example, shortness of breath, regular cold, hack, wheezing, asthma assaults, throat blockage and respiratory aggravations (Nagar et al., 2014; Mehmood et al., 2015).

Over the past few decades, the problem of air pollutant emissions has received widespread public and academic attention in Pakistan (Aziz et al., 2015a; Ali et al., 2015; Mehmood et al., 2015). A comprehensive study was conducted to investigate monthly changes in ozone $\left(\mathrm{O}_{3}\right)$, sulphur dioxide $\left(\mathrm{SO}_{2}\right)$, carbon monoxide $(\mathrm{CO})$ and particulate matter $\left(\mathrm{PM}_{10}\right)$ in the city of Shiraz, Iran. The concentrations of pollutants and $\mathrm{PM}_{10}$ were monitored for consecutive four years (2006 to 2009). The concentration of ambient air quality parameters varies significantly every month. Ambient air quality monitoring data collected in Shiraz city center Iran showed seasonal variations in concentration of sulphur dioxide $\left(\mathrm{SO}_{2}\right)$, carbon monoxide (CO) and $\mathrm{PM}_{10}$ (Ashraf et al., 2013). Irrespirable suspended particulate (RSP) or $\mathrm{PM}_{10}$ and vapor toxins, for example nitrogen oxides are known to effectively affect human wellbeing and the connection between air contaminations and wellbeing has been broadly contemplated (Borghi et al., 2017). Urban air contamination is generally an aftereffect of burning of petroleum products, which are used in transportation, educational, residential and industrial operations. Household air pollution (HAP), also called indoor air contamination (IAP), is a genuine thing of worry in country spaces, as greater part of the population keeps on relying upon conventional biomass for cooking and space warming and relies upon lamp oil or other fossil energies for lighting, which certainly elevated amount of HAP. Over 70\% of the population in India relies upon conventional powers (kindling, edit buildup, dairy animals waste, coal and lignite) for cooking and practically 32\% rely upon lamp oil for lighting purposes. Around 3 billion individuals on the planet (over $40 \%$ of the worldwide population) depend on conventional biomass to cook and an expected 500 million family units depend on lamp oil (WHO, 2015; Sarnat et al., 2008).

Fine PM for example $\mathrm{PM}_{2.5}$ is the most imperative particles and hard to gauge. From smoke of burning, $\mathrm{PM}_{2.5}$ is the absolute hazard causing particles for human beings (Pokhrel et al., 2015; Fishbain et al., 2017). Children are more sensitive to PM than older folks as their respiratory system is more prone and vulnerable to fine particles. PM cause respiratory and cardiovascular aliments in human beings. $\mathrm{PM}_{2.5}$ causes 0.8 million unexpected life losses each year (Wu et al., 2018; Araujo et al., 2014). PM causes asthma, impacts lung's function, dismalness and mortality in individuals. $\mathrm{PM}_{2.5}$ particles are increasingly lethal and that is the main reason for impacts on human health, because these particles may incorporate acids, nitrates, sulfates, metal and particles of various synthetics ingested onto their surfaces (Rao and Reddy, 2014). These particles infiltrate profoundly into the lungs and hold there for long period of time (Khan et al., 2015). PM is known to be more common air poison than other air contaminants in all urban zones of the world and the impact of PM on nature and human health are devastating (Alam et al., 2015).

It has been reported that $70 \%$ population live in remote and rural setups in Pakistan (Ashraf et al., 2013). Due to abrupt increase in population growth of Pakistan, urban areas are densely polluted (Bo et al., 2017). Energy consumed for domestic activities come from organic fuels such as dung, wood, natural gas and crop residues. Wood has been used as a fuel by $54 \%$ of the Pakistani population. Other sources of air pollution are heavy transportation and traffic systems (Alam et al., 2015; 
Ashraf et al., 2013). Vehicular emissions account for $27.4 \%$, kiln facilities emit $11 \%$, solid soil particles and dust from the road contribute $35.9 \%$, and industries accounted for $12.9 \%$ in the production of PM in Pakistan (Alam et al., 2015). Haripur is an emerging city surrounded by Hattar Industrial Estate (HIE), the second biggest industrial estate of the Khyber Pakhtunkhwa province and some suburban areas from where peoples are migrating towards the city for employment, recreation, business and educational purposes. Due to industrial activities, heavy traffic and construction activities, the concentration of PM is increasing in the air of the Haripur city, Pakistan. Therefore, objectives of this study were to assess concentration of PM in ambient air of different settings and its associated health risks in Haripur city, Pakistan.

\section{Materials and Methods}

\subsection{Study area}

The present study was designed to find out the concentration of particulate matter (PM) in air of different settings and their associated health risks in Haripur city, Pakistan. Haripur city is situated in Hazara Division of the Khyber Pakhtunkhwa province of Pakistan. Samples of air were collected from different sites of study area. A total of twenty-three (23) samples were taken from different representative sites in Haripur city. The sampling sites included hospitals, schools and recreational parks in Khalabat Township, Haripur, Hattar and pere areas as documented in Table 1. All samples were collected with

Table 1. Concentration of PM in different environmental settings of Haripur city, Pakistan.

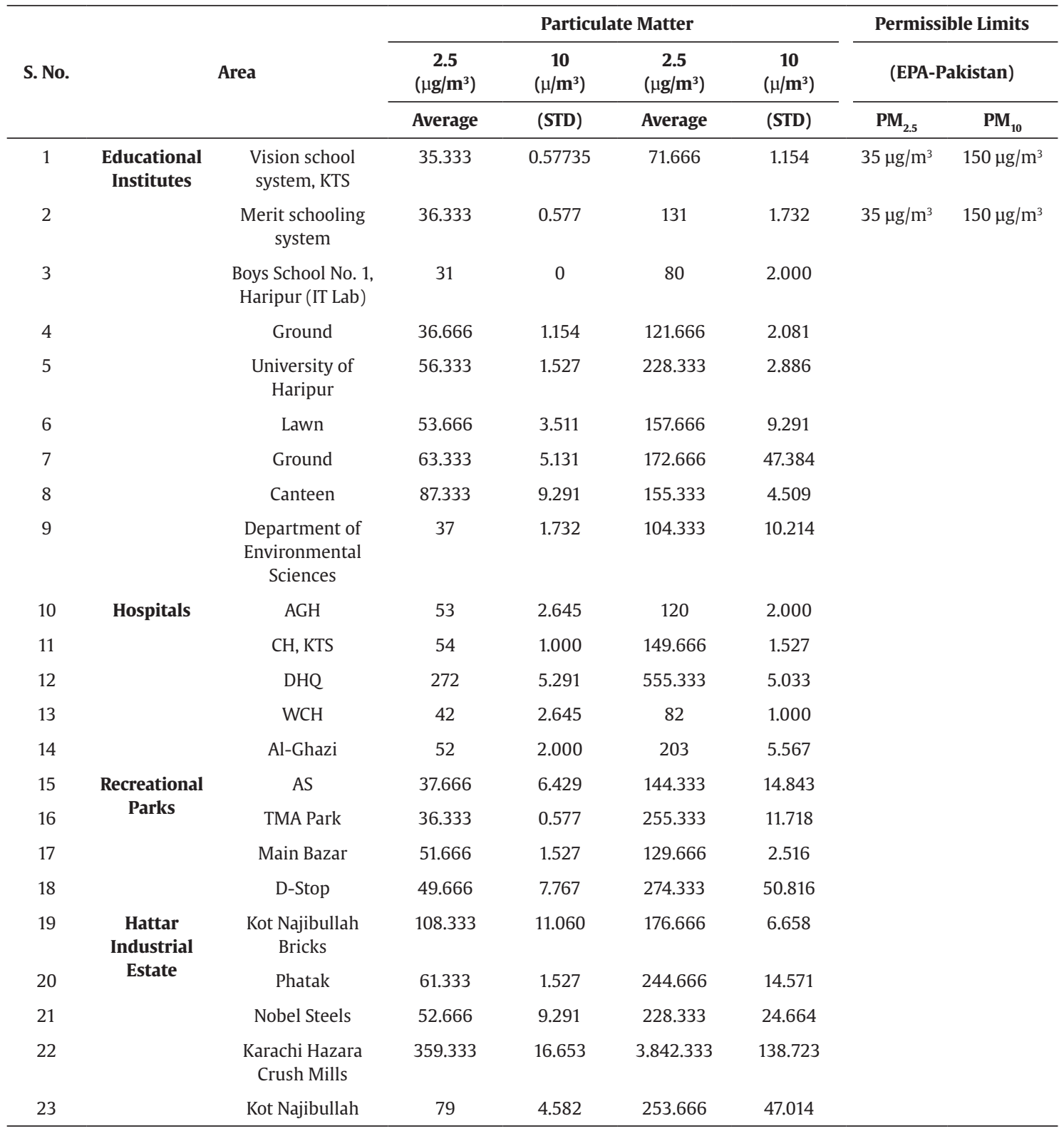


the help of Youngteng YT-HPC 3000a Handle Particulate Counter. Each sample was marked and labeled with sample number, date, time and site of collection. Coordinates of the selected sites were taken through GPS for making map of the study area as can be seen in Figure 1.

\subsection{Youngteng yt-hpc 3000a Handle Particulate Counter}

Youngteng yt-hpc 3000a handle particulate counter was used to measure the concentration of $\mathrm{PM}_{10}$ and $\mathrm{PM}_{2.5}$, respectively. It was taken to the sampling site and the sensors installed in the device automatically detect the PM particles, measure it and give the readings on display or screen of the device. Its portable device and can easily be read as the PM concentration is showed in its screen. Its give PM concentration in digital or numerical form.

\subsection{Determination of health impacts}

To find the health impacts of the particulate matter(PM), the following Equation 1 was applied to calculate air quality index (AQI) of Haripur city, Pakistan (Ashraf et al., 2013).

$$
A Q I=\frac{\text { Concentrtion of Pollutant in air }}{\text { Standard value of that Pollutant }}
$$

Where, AQI stands for Air quality index of a particular pollutant

\subsection{Statistical analysis}

All the data gathered were statistically analyzed. The mean values of the PM readings are calculated to show the significance of the treatments. One-way ANOVA and correlations analysis was done through SPSS. Standard deviation was calculated to check the significance of the results health risk index.

\section{Results and Discussions}

\subsection{Concentration of PM in educational institutes}

The concentration of PM (2.5 and 10) was measured in five educational institutes of urban and suburban vicinities i.e., Vision School System (VSS), Merit Schooling System (MSS), Government Boys School, Environmental Protection Agency District Office, and The University of Haripur ( $\mathrm{UoH})$ as can be seen in Table 1 and Figure 2. The maximum concentration of $\mathrm{PM}_{2.5}$ and $\mathrm{PM}_{10}$, was found in $\mathrm{UoH}$ i.e., $59.6 \mu \mathrm{g} / \mathrm{m}^{3}$ and $173.4 \mu \mathrm{g} / \mathrm{m}^{3}$, respectively. Four samples were taken from the University of Haripur situated in Haripur city. The mean concentration of $\mathrm{PM}_{2.5}$ in the university chowk was $56.33 \mu \mathrm{g} / \mathrm{m}^{3}$ with range of $55-58 \mu \mathrm{g} / \mathrm{m}^{3}$ and standard deviation \pm 1.5727 . While the mean concentration of $\mathrm{PM}_{10}$ was $228.33 \mu \mathrm{g} / \mathrm{m}^{3}$ with the range of $228-230 \mu \mathrm{g} / \mathrm{m}^{3}$

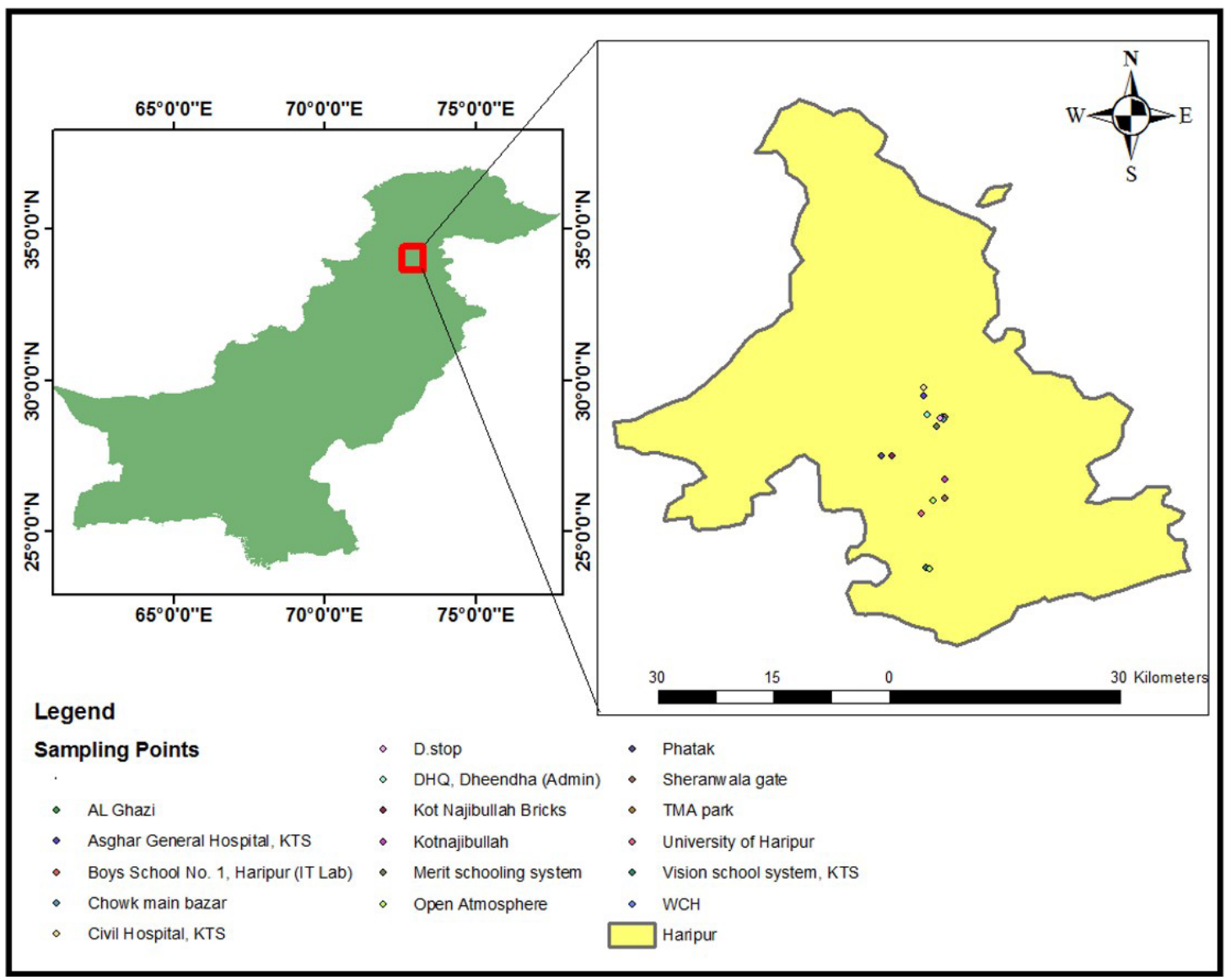

Figure 1. Location Map of the study area. 
Table 2. Air Quality Index (AQI) of PM in different environmental settings of Haripur city, Pakistan.

\begin{tabular}{|c|c|c|c|c|c|c|}
\hline \multirow{3}{*}{ S. No. } & & \multirow{3}{*}{ Area } & \multicolumn{4}{|c|}{$\mathbf{R i}$} \\
\hline & & & \multicolumn{2}{|c|}{$2.5\left(\mu \mathrm{g} / \mathrm{m}^{3}\right)$} & \multicolumn{2}{|c|}{$10\left(\mu / \mathbf{m}^{3}\right)$} \\
\hline & & & Average & (STD) & Average & (STD) \\
\hline 1 & Educational & Vision school system, KTS & 1.009 & 0.016 & 0.477 & 0.007 \\
\hline 2 & tutes & Merit schooling system & 1.038 & 0.016 & 0.873 & 0.011 \\
\hline 3 & & Boys School No. 1, Haripur (IT Lab) & 0.885 & 0 & 0.533 & 0.013 \\
\hline 4 & & Ground & 1.047 & 0.032 & 0.811 & 0.013 \\
\hline 5 & & University of Haripur & 1.609 & 0.043 & 1.522 & 0.019 \\
\hline 6 & & Lawn & 1.533 & 0.100 & 1.051 & 0.061 \\
\hline 7 & & Ground & 1.809 & 0.146 & 1.151 & 0.315 \\
\hline 8 & & Canteen & 2.495 & 0.265 & 1.035 & 0.030 \\
\hline 9 & & $\begin{array}{l}\text { Department of Environmental } \\
\text { Sciences }\end{array}$ & 1.057 & 0.049 & 0.695 & 0.068 \\
\hline 10 & Hospitals & AGH & 1.514 & 0.075 & 0.800 & 0.013 \\
\hline 11 & & $\mathrm{CH}, \mathrm{KTS}$ & 1.542 & 0.028 & 0.997 & 0.010 \\
\hline 12 & & DHQ & 1.200 & 0.075 & 0.546 & 0.006 \\
\hline 13 & & WCH & 1.485 & 0.057 & 1.353 & 0.037 \\
\hline 14 & & Al-Ghazi & 1.190 & 0.059 & 0.564 & 0.030 \\
\hline 15 & Recreational & AS & 1.076 & 0.183 & 0.962 & 0.098 \\
\hline 16 & Parks & TMA Park & 1.038 & 0.016 & 1.702 & 0.078 \\
\hline 17 & & Main Bazar & 1.476 & 0.043 & 0.864 & 0.016 \\
\hline 18 & & D-Stop & 1.419 & 0.221 & 1.828 & 0.338 \\
\hline 19 & Hattar & Kot Najibullah Bricks & 3.095 & 0.316 & 1.177 & 0.044 \\
\hline 20 & $\begin{array}{l}\text { Industrial } \\
\text { Estate }\end{array}$ & Phatak & 1.752 & 0.043 & 1.631 & 0.097 \\
\hline 21 & & Nobel Steels & 1.504 & 0.265 & 1.522 & 0.164 \\
\hline 22 & & Karachi Hazara Crush Mills & 10.266 & 0.475 & 25.615 & 0.924 \\
\hline 23 & & Kot Najibullah & 2.257 & 0.130 & 1.691 & 0.313 \\
\hline
\end{tabular}



Figure 2. Mean concentration of Ri for $\mathrm{PM}_{10}$ and $\mathrm{PM}_{2.5}$ in the air of Educational Institutes. The error bars indicate the standard deviations. and standard deviation \pm 2.886 . The mean concentration of $\mathrm{PM}_{2.5}$ in the lawn at the university was $53.67 \mu \mathrm{g} / \mathrm{m}^{3}$ with the range of $50-57 \mu \mathrm{g} / \mathrm{m}^{3}$ and standard deviation \pm 3.511 . While the mean concentration of $\mathrm{PM}_{10}$ was $157.66 \mu \mathrm{g} / \mathrm{m}^{3}$ with range of $150-168 \mu \mathrm{g} / \mathrm{m}^{3}$ and standard deviation \pm 9.29. Similarly, the mean concentration of $\mathrm{PM}_{2.5}$ in the ground of university was $63.33 \mu \mathrm{g} / \mathrm{m}^{3}$ with the range of $59-69 \mu \mathrm{g} / \mathrm{m}^{3}$ and standard deviation \pm 5.13 . While the mean concentration of $\mathrm{PM}_{10}$ was $172.66 \mu \mathrm{g} / \mathrm{m}^{3}$ with the range of $118-20 \mu \mathrm{g} / \mathrm{m}^{3}$ and standard deviation \pm 47.38 . The mean concentration of $\mathrm{PM}_{2.5}$ in the canteen was $87.33 \mu \mathrm{g} / \mathrm{m}^{3}$ with range of $77-95 \mu \mathrm{g} / \mathrm{m}^{3}$ and standard deviation \pm 9.29 . While the mean concentration of $\mathrm{PM}_{10}$ was $155.33 \mu \mathrm{g} / \mathrm{m}^{3}$ with the range of $151-160 \mu \mathrm{g} / \mathrm{m}^{3}$ and standard deviation \pm 4.51 . The high concentration of PM in University of Haripur was found due to the playing activities in the ground and the parking area inside the university. Similarly, minimum concentration was found in Vision Schooling System (VSS)-Kalabat Town Ship (KTS) i.e., $35 \mu \mathrm{g} / \mathrm{m}^{3}$ and $73 \mu \mathrm{g} / \mathrm{m}^{3}$ of $\mathrm{PM}_{2.5}$ and $\mathrm{PM}_{10}$, respectively. The concentration of PM at all 
locations was found exceeding permissible limits of NEQS Pak-EPA i.e., $35 \mu \mathrm{g} / \mathrm{m}^{3}$ and $150 \mu \mathrm{g} / \mathrm{m}^{3}$ according to 24 hours exposure while $120 \mu \mathrm{g} / \mathrm{m}^{3}$ and $15 \mu \mathrm{g} / \mathrm{m}^{3}$ with reference to annual exposure of $\mathrm{PM}_{2.5}$ and $\mathrm{PM}_{10}$ respectively (Vallente Junior et al., 2017). Different schools had sudden increase in concentration of $\mathrm{PM}_{2.5}$ and $\mathrm{PM}_{10}$ due to massive activities of children like running and playing in and around school grounds. The location of schools was found to be important in PM pollution level, means if the school was present in congested and urban area then there was more PM pollution noted. Overall, an expressive correlation can be proven to show that higher road traffic especially the presence of tucks/trailers and private vehicles has been part to the poor ambient air quality in certain schools at Haripur city, Pakistan.

The hourly mean concentration of $\mathrm{PM}_{10}$ varied from $39.0 \mu \mathrm{g} / \mathrm{m}^{3}$ to $166.3 \mu \mathrm{g} / \mathrm{m}^{3}$. The maximum value exceeded the NAAQS limit by $10.9 \%$. $\mathrm{PM}_{2.5}$ hourly mean concentration varied between $23.7 \mu \mathrm{g} / \mathrm{m}^{3}$ and $126.0 \mu \mathrm{g} / \mathrm{m}^{3}$. The highest value exceeded the limit by 260\% (Abali et al., 2018). In the present study, it was observed that ambient air was more polluted as compared to indoor air and had significant impact on the indoor levels of $\mathrm{PM}_{2.5}$. Apart from the outdoor sources, student occupancy level also affected the indoor concentrations. Air Quality Health Index report of Canada had shown that the range from $1-3$ is low risk; 4-6 on scale is moderate while $7-10$ is at high risk. The minimum mean value of health index (Ri) for $\mathrm{PM}_{2.5}$ and $\mathrm{PM}_{10}$ calculated at private educational institutes, Vision school system and Merit Schooling System was in low-risk value in Haripur city, Pakistan. Akinfolarin et al. (2017) reported high concentration of $\mathrm{PM}_{2.5}$ and $\mathrm{PM}_{10}$ in Harcourt and concluded that these levels might be harmful to public health and the environment. Similarly, Osimobi et al. (2019) observed high level of $\mathrm{PM}_{2.5}$ and $\mathrm{PM}_{10}$ in University of Nigeria, which in accordance with the results of the present study. The mean value of Ri for concentration of $\mathrm{PM}_{2.5}$ in Boys School Haripur was 0.885 with STD \pm 0 and mean of Ri for concentration of $\mathrm{PM}_{10} 0.5333$ with STD \pm 0.013 . The ground of Boys school was sampled with mean value of Ri for concentration of $\mathrm{PM}_{2.5} 1.047$ with STD \pm 0.0329 while mean of Ri for concentration of $\mathrm{PM}_{10}$ was 0.811 with STD \pm 0.019 . The mean value of Ri for concentration of $\mathrm{PM}_{2.5}$ in University of Haripur was 1.609 with STD \pm 0.043 and mean of Ri for concentration of $\mathrm{PM}_{10}$ was noticed 0.811 with STD \pm 0.013 . The mean value of Ri for concentration of $\mathrm{PM}_{2.5}$ in lawn of University of Haripur was 1.533 with STD \pm 0.100 and mean of Ri for concentration of $\mathrm{PM}_{10} 1.051$ with STD \pm 0.061. The mean value of Ri for concentration of $\mathrm{PM}_{2.5}$ in ground of University of Haripur was 1.809 with STD \pm 0.146 and mean of Ri for concentration of PM $_{10} 1.151$ with STD \pm 0.315 . The mean value of $\mathrm{Ri}$ for concentration of $\mathrm{PM}_{2.5}$ in canteen of the University of Haripur was 2.495 with STD \pm 0.265 and mean of $\mathrm{Ri}$ for concentration of $\mathrm{PM}_{10} 1.035$ with STD \pm 0.030 . The mean value of Ri for concentration of $\mathrm{PM}_{2.5}$ in Department of Environmental Sciences of the University of Haripur was 1.057 with STD \pm 0.494 and mean of Ri for concentration of $\mathrm{PM}_{10} 0.695$ with STD \pm 0.068 . The results of present study had shown that about $67 \%$ of students have caught cough in educational institutes while $33 \%$ got cough at home.

\subsection{Health risks associated with PM in educational institutes}

The mean value of health index Ri for $\mathrm{PM}_{2.5}$ calculated at Vision school system was 1.009 with STD \pm 0.016 . While the mean value of Ri for $\mathrm{PM}_{10}$ was 0.478 with STD \pm 0.007 (Table 1). Merit Schooling System was the private educational institute where the value of Ri for concentration of $\mathrm{PM}_{2.5}$ was noticed in mean value of 1.038 with STD \pm 0.016 as can be seen in Table 2 . The mean value of Ri for concentration of $\mathrm{PM}_{10}$ was found 0.873 with STD \pm 0.011 . The mean value of Ri for concentration of $\mathrm{PM}_{2.5}$ in Boys School Haripur was 0.885 with STD \pm 0 and mean of Ri for concentration of $\mathrm{PM}_{10} 0.533$ with STD \pm 0.013 . The ground of Boys school was recorded with mean value of Ri for concentration of $\mathrm{PM}_{2.5} 1.047$ with STD \pm 0.032 while mean of Ri for concentration of $\mathrm{PM}_{10}$ was 0.811 with STD \pm 0.019 . The mean value of Ri for concentration of $\mathrm{PM}_{2.5}$ in University of Haripur was 1.609 with STD \pm 0.043 and mean of Ri for concentration of $\mathrm{PM}_{10}$ was noticed 0.811 with STD \pm 0.013 . The mean value of Ri for concentration of $\mathrm{PM}_{2.5}$ in lawn of University of Haripur was 1.533 with STD \pm 0.100 and mean of Ri for concentration of $\mathrm{PM}_{10} 1.051$ with STD \pm 0.061 . The mean value of Ri for concentration of $\mathrm{PM}_{2.5}$ in ground of University of Haripur was 1.809 with $\mathrm{STD} \pm 0.146$ and mean of Ri for concentration of $\mathrm{PM}_{10} 1.151$ with STD \pm 0.315 . The mean value of Ri for concentration of $\mathrm{PM}_{2.5}$ in canteen of University of Haripur was 2.495 with STD \pm 0.265 and mean of Ri for concentration of $\mathrm{PM}_{10} 1.035$ with STD \pm 0.030 . The mean value of Ri for concentration of $\mathrm{PM}_{25}$ in DES of University of Haripur was 1.057 with STD \pm 0.494 and mean of Ri for concentration of $\mathrm{PM}_{10} 0.695$ with STD \pm 0.068 .

\subsection{Concentration of PM in hospitals}

The concentration of PM (2.5 and 10) was measured in five hospitals of urban and suburban vicinities i.e., Asghar General Hospital (AGH) and Civil Hospital-KTS, District Head Quarter (DHQ) Hospital-Dheendha, Women and Children Hospital (WCH) and Al-ghazi Hospital-Haripur as presented in Table 1 and Figures 3, 4. The maximum concentration was found in DHQ i.e., $66.9 \mu \mathrm{g} / \mathrm{m}^{3}$ and $215.1 \mu \mathrm{g} / \mathrm{m}^{3}$ of $\mathrm{PM}_{2.5}$ and $\mathrm{PM}_{10}$, respectively. While the minimum concentration was found in WCH i.e., $43 \mu \mathrm{g} / \mathrm{m}^{3}$ and $82 \mu \mathrm{g} / \mathrm{m}^{3}$ of $\mathrm{PM}_{2.5}$ and $\mathrm{PM}_{10}$ respectively. The concentration of PM at all locations was found exceeding permissible limits of NEQS PakEPA, i.e., $35 \mu \mathrm{g} / \mathrm{m}^{3}$ and $150 \mu \mathrm{g} / \mathrm{m}^{3}$ according to 24 hours exposure while $120 \mu \mathrm{g} / \mathrm{m}^{3}$ and $15 \mu \mathrm{g} / \mathrm{m}^{3}$ with reference to annual exposure of $\mathrm{PM}_{2.5}$ and $\mathrm{PM}_{10}$ respectively. The main reason for the high concentration is the locality and the public interaction on the said sample sites. The hospitals are located on the main road where traffic is heavy and other commercial activities are at high rate.

\subsection{Health risks associated with PM in hospitals}

Asghar General Hospital was accounted for mean value of Ri for concentration of $\mathrm{PM}_{2.5} 1.514$ with STD \pm 0.075 while mean of Ri for concentration of $\mathrm{PM}_{10}$ was 0.8 with STD \pm 
0.013 (Table 1). Among hospitals, sampling civil hospital was the government hospital of KTS where the mean value of Ri for concentration of $\mathrm{PM}_{2.5}$ was 1.542 with STD \pm 0.028 while mean of Ri for concentration of $\mathrm{PM}_{10}$ was 0.997 with STD \pm 0.010 . WC Hospital was reported mean value of Ri for concentration of $\mathrm{PM}_{2.5} 1.2$ with STD \pm 0.075 while mean of Ri for concentration of $\mathrm{PM}_{10}$ was 0.546 with STD \pm 0.006 as can be seen in Table 2. Al-ghazi hospital was notice with mean value of Ri for concentration of $\mathrm{PM}_{2.5}$ 1.486 with STD \pm 0.057 while mean of Ri for concentration of $\mathrm{PM}_{10}$ was 1.353 with STD \pm 0.037 . DHQ is a government health facility situated in Haripur where patients from the whole district and pere areas visit for treatment. The mean value of Ri for concentration of $\mathrm{PM}_{2.5}$ was 1.190 with STD \pm 0.059 while mean of $\mathrm{Ri}$ for concentration of $\mathrm{PM}_{10}$ was 0.564 with STD \pm 0.030 .

\subsection{Concentration of $P M$ in recreational parks}

The concentration of PM (2.5 and 10) was measured in five recreational parks of urban and suburban vicinities



Figure 3. Mean concentration of $\mathrm{PM}_{10}$ and $\mathrm{PM}_{25}$ in the air of Hospitals of Haripur. The error bars indicate the standard deviations.



Figure 4. Mean concentration of Ri for $\mathrm{PM}_{10}$ and $\mathrm{PM}_{2.5}$ in the air of Hospitals of Haripur. The error bars indicate the standard deviations. i.e., Akhtar Nawaz Stadium-KTS, TMA, Main Bazar, D-Stop and Sheranwala Gate-Haripur as shown in Table 1 and Figures 5 and 6 . The maximum concentration was found in Sheranwala Gate i.e., $51 \mu \mathrm{g} / \mathrm{m}^{3}$ and $317 \mu \mathrm{g} / \mathrm{m}^{3}$ of $\mathrm{PM}_{2.5}$ and $\mathrm{PM}_{10}$, respectively. While the minimum concentration was found in AN stadium-KTS i.e., $37.66 \mu \mathrm{g} / \mathrm{m}^{3}$ and $111 \mu \mathrm{g} / \mathrm{m}^{3}$ of $\mathrm{PM}_{25}$ and $\mathrm{PM}_{10}$ respectively. The concentration of PM at all locations was found exceeding permissible limits of NEQS Pak-EPA i.e., $35 \mu \mathrm{g} / \mathrm{m}^{3}$ and $150 \mu \mathrm{g} / \mathrm{m}^{3}$ according to 24 hours exposure while $120 \mu \mathrm{g} / \mathrm{m}^{3}$ and $15 \mu \mathrm{g} / \mathrm{m}^{3}$ with reference from to annual exposure of $\mathrm{PM}_{2.5}$ and $\mathrm{PM}_{10}$ respectively.

The sample taken from the Akhtar Nawaz Shaheed Stadium situated in Kalabat Town Ship (KTS) where mean concentration of $\mathrm{PM}_{2.5}$ was $37.66 \mu \mathrm{g} / \mathrm{m}^{3}$ with the range of $33-45 \mu \mathrm{g} / \mathrm{m}^{3}$ and STD \pm 6.4290 and the mean concentration of $\mathrm{PM}_{10}$ was $144.333 \mu \mathrm{g} / \mathrm{m}^{3}$ with range of $128-157 \mu \mathrm{g} / \mathrm{m}^{3}$ and STD \pm 14.843 . Similarly, the mean concentration of $\mathrm{PM}_{2.5}$ in the Tehsil Municipal Administration (TMA) Park was $36.333 \mu \mathrm{g} / \mathrm{m}^{3}$ with range of $36-37 \mu \mathrm{g} / \mathrm{m}^{3}$ and STD \pm 0.577 while the mean concentration of $\mathrm{PM}_{10}$ was $255.33 \mu \mathrm{g} / \mathrm{m}^{3}$ with

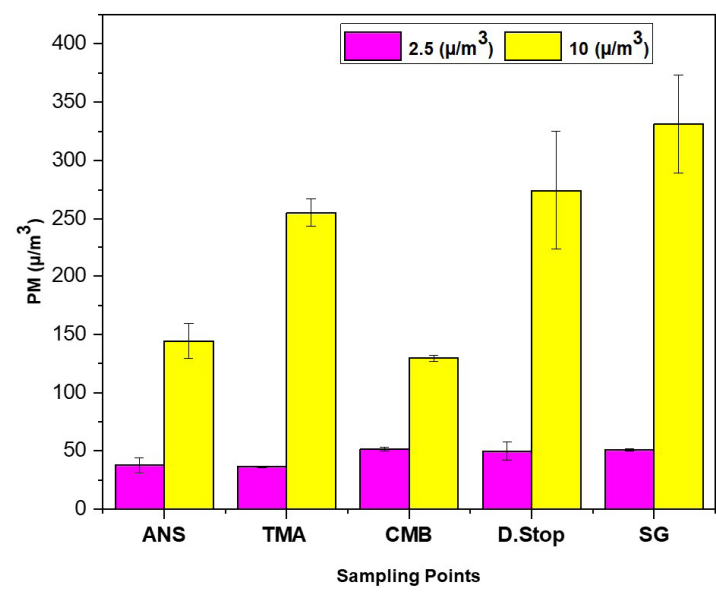

Figure 5. Mean concentration of $\mathrm{PM}_{10}$ and $\mathrm{PM}_{2.5}$ in the air of Recreational Parks of Haripur. The error bars indicate the standard deviations.

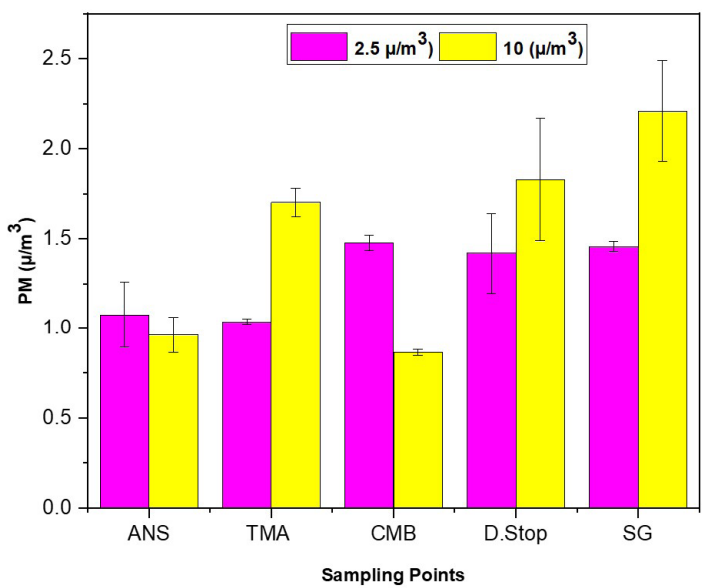

Figure 6. Mean concentration of Ri for $\mathrm{PM}_{10}$ and $\mathrm{PM}_{2.5}$ in the air of Recreational Parks of Haripur. The error bars indicate the standard deviations. 
range of $242-264 \mu \mathrm{g} / \mathrm{m}^{3}$ and STD \pm 11.71 . The sample taken from the Chowk Main Bazar situated in KTS with latitude 33.99313 and longitude 72.933. The mean concentration of $\mathrm{PM}_{2.5}$ was $51.666 \mu \mathrm{g} / \mathrm{m}^{3}$ with the range of $50-53 \mu \mathrm{g} / \mathrm{m}^{3}$ and STD \pm 1.527 and the mean concentration of $\mathrm{PM}_{10}$ was $129.666 \mu \mathrm{g} / \mathrm{m}^{3}$ with range of $127-132 \mu \mathrm{g} / \mathrm{m}^{3}$ and STD \pm 2.516 . Similarly, the mean concentration of $\mathrm{PM}_{2.5}$ in the D. Stop was $49.66 \mu \mathrm{g} / \mathrm{m}^{3}$ with range of $41-56 \mu \mathrm{g} / \mathrm{m}^{3}$ and STD \pm 7.767 while the mean concentration of $\mathrm{PM}_{10}$ was $274.333 \mu \mathrm{g} / \mathrm{m}^{3}$ with range of $216-309 \mu \mathrm{g} / \mathrm{m}^{3}$ and STD \pm 50.8166 . Sheranwala gate is the public place existing in District Haripur where the mean concentration of $\mathrm{PM}_{25}$ was $51 \mu \mathrm{g} / \mathrm{m}^{3}$ with the range of $51-52 \mu \mathrm{g} / \mathrm{m}^{3}$ and STD \pm 1 and the mean concentration of $\mathrm{PM}_{10}$ was $331.666 \mu \mathrm{g} / \mathrm{m}^{3}$ with range of $283-360 \mu \mathrm{g} / \mathrm{m}^{3}$ and STD \pm 42.099 . Cesaroni et al., 2014 and Stafoggia et al., 2014 studied the angina problems and strokes due to high exposure of PM in air. This long-term exposure was causing severe cardiovascular and respiratory problems (Thurston et al., 2017) and had shown many health effects like inspired vascular function, high blood pressure, stroke, myocardial infraction and also neurological diseases including Alzheimer's and Parkinson's diseases. The health effects caused due to traffic and coal fired power stations emissions are greater than all other sources.

\subsection{Health risks associated with $P M$ in recreational areas}

Akhtar Nawaz Stadium was recreational area in the KTS with mean value of Ri for concentration of $\mathrm{PM}_{2.5} 1.0762$ with STD \pm 0.1837 while mean of Ri for concentration of $\mathrm{PM}_{10}$ was 0.9622 with STD \pm 0.098 (Table 1 and Table 2). The mean value of Ri for concentration of $\mathrm{PM}_{2.5}$ in TMA was 1.03809 with STD \pm 0.01649 while mean of Ri for concentration of $\mathrm{PM}_{10}$ was 1.70227 with STD \pm 0.078126 . Chowk main bazar was recreational area with mean value of Ri for concentration of $\mathrm{PM}_{2.5} 1.4762$ with STD \pm 0.0436 while mean of Ri for concentration of $\mathrm{PM}_{10}$ was 0.8644 with STD \pm 0.0167 . D-stop was notice with mean value of Ri for concentration of $\mathrm{PM}_{2.5} 1.419$ with STD \pm 0.2219 while mean of Ri for concentration of $\mathrm{PM}_{10}$ was 1.8288 with STD \pm 0.33878 . Sheranwala gate had the mean value of Ri for concentration of $\mathrm{PM}_{2.5} 1.4571$ with STD \pm 0.0285 while mean of Ri for concentration of $\mathrm{PM}_{10}$ was 2.2088 with STD \pm 0.280661 .

\subsection{Concentration of PM in Hattar Industrial Estate, Haripur city}

The concentration of PM (2.5 and 10) was measured in five locations at Hattar Industrial Estate (HIE) i.e., Kot Najibullah Bricks, Phatak, Nobel Steels, Karachi Hazara Crushing mill and Kot Najibullah as presented in Table 1 and Figures 7 and 8 . The maximum concentration was found in Karachi Hazara crushing mill i.e., $354 \mu \mathrm{g} / \mathrm{m}^{3}$ and $3739 \mu \mathrm{g} / \mathrm{m}^{3}$ of $\mathrm{PM}_{2.5}$ and $\mathrm{PM}_{10}$, respectively. While the minimum concentration was found in Phatak i.e., $60 \mu \mathrm{g} / \mathrm{m}^{3}$ and $231 \mu \mathrm{g} / \mathrm{m}^{3}$ of $\mathrm{PM}_{2.5}$ and $\mathrm{PM}_{10}$ respectively. The concentration of PM at all locations was found exceeding permissible limits of NEQS Pak-EPA i.e., $35 \mu \mathrm{g} / \mathrm{m}^{3}$ and $150 \mu \mathrm{g} / \mathrm{m}^{3}$ of PM $\mathrm{PM}_{2.5}$ and $\mathrm{PM}_{10}$ respectively according to 24 hours exposure. The sample taken from the Kot Najibullah Bricks situated in Haripur with latitude 33.94998 and longitude 72.87298 . The

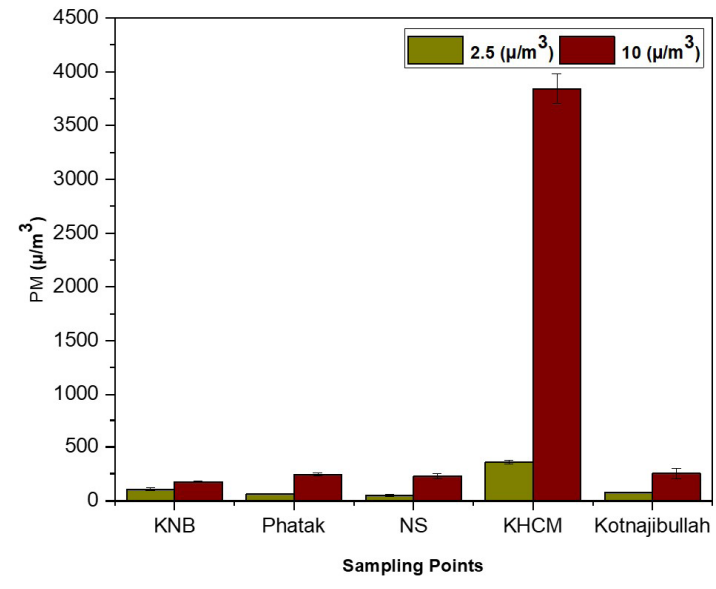

Figure 7. Mean concentration of $\mathrm{PM}_{10}$ and $\mathrm{PM}_{2.5}$ in the air of Hattar Industrial Estate. The error bars indicate the standard deviations.

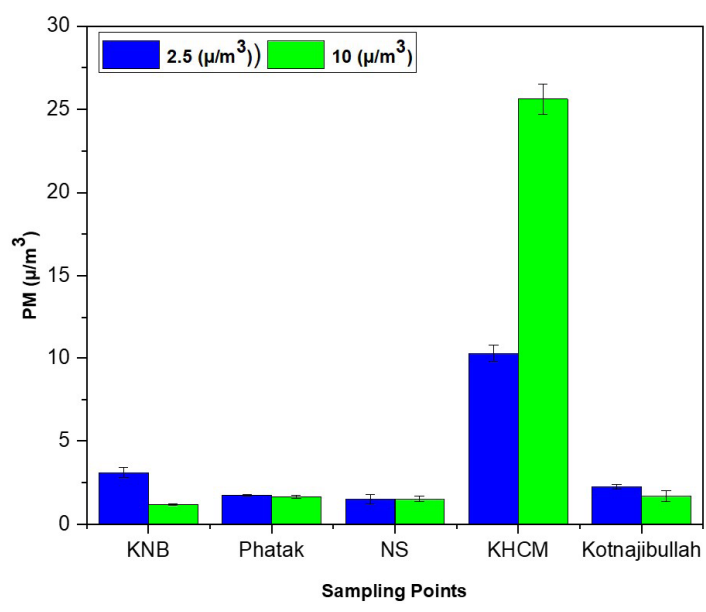

Figure 8. Mean concentration of Ri for $\mathrm{PM}_{10}$ and $\mathrm{PM}_{2.5}$ in the air of Hattar Industrial Estate. The error bars indicate the standard deviations.

mean concentration of $\mathrm{PM}_{2.5}$ is was $108.3333333 \mu \mathrm{g} / \mathrm{m}^{3}$ with the range of $98-120 \mu \mathrm{g} / \mathrm{m}^{3}$ and STD \pm 11.06044002 and the mean concentration of $\mathrm{PM}_{10}$ was $176.6666667 \mu \mathrm{g} / \mathrm{m}^{3}$ with range of $171-184 \mu \mathrm{g} / \mathrm{m}^{3}$ and STD \pm 6.658328118 . Phatak was the point at the very entrance of HIE at 33.94998 latitude and 72.86071 longitude. The mean concentration of $\mathrm{PM}_{2.5}$ at Phatak was $61.33333333 \mu \mathrm{g} / \mathrm{m}^{3}$ with range of $61-63 \mu \mathrm{g} / \mathrm{m}^{3}$ and STD \pm 1.5275 while the mean concentration of $\mathrm{PM}_{10}$ was $244.6666667 \mu \mathrm{g} / \mathrm{m}^{3}$ with range of $231-360 \mu \mathrm{g} / \mathrm{m}^{3}$ and STD \pm 14.571662 . Kot Najibullah is the village existing in and situated at 33.92265 latitude and 72.93417 longitudes. The mean concentration of $\mathrm{PM}_{2.5}$ is was $51 \mu \mathrm{g} / \mathrm{m}^{3}$ with the range of $51-52 \mu \mathrm{g} / \mathrm{m}^{3}$ and STD \pm 1 and the mean concentration of $\mathrm{PM}_{10}$ was $331.6666667 \mu \mathrm{g} / \mathrm{m}^{3}$ with range of $283-360 \mu \mathrm{g} / \mathrm{m}^{3}$ and STD \pm 42.099 . Ostro et al., 2011 and Sarnat et al., 2008 examined that coal-fired power stations generating $\mathrm{PM}_{2.5}$ caused more severe health issues as compared to total $\mathrm{PM}_{2.5}$ mass circulating. The adverse impacts on health are associated with exposure of PM generating from coal-fired 
power stations. Theses emissions may be direct or indirect and cause cardiovascular issues.

\subsection{Health risks associated with PM in Hattar Industrial Estate}

The mean value of Ri for concentration of $\mathrm{PM}_{2.5}$ on Kot Najibullah Bricks was 3.095 with STD \pm 0.316 while mean of Ri for concentration of $\mathrm{PM}_{10}$ was 1.752 with STD \pm 0.044 (Table 2). The mean value of Ri for concentration of $\mathrm{PM}_{2.5}$ in Phatak was 1.752 with STD \pm 0.043 while mean of Ri for concentration of $\mathrm{PM}_{10}$ was 1.631 with STD \pm 0.097 . Nobel Steels had mean value of Ri for concentration of $\mathrm{PM}_{25} 1.504$ with STD \pm 0.265 while mean of Ri for concentration of $\mathrm{PM}_{10}$ was 1.522 with STD \pm 0.164 . Karachi Hazara crush mills was notice with mean value of Ri for concentration of $\mathrm{PM}_{2.5}$ 10.266 with STD \pm 0.475 while mean of Ri for concentration of $\mathrm{PM}_{10}$ was 25.615 with STD \pm 0.924 . Kot Najibullah had the mean value of Ri for concentration of $\mathrm{PM}_{2.5} 2.257$ with STD \pm 0.130 while mean of Ri for concentration of $\mathrm{PM}_{10}$ was 1.691 with STD \pm 0.313 .

\section{Conclusions}

The present study found out that there were heavy concentrations of PM of both fractions $\mathrm{PM}_{2.5}$ and $\mathrm{PM}_{10}$ present in the air of different settings of Haripur city, Pakistan. The sources of PM at all the sampling points were due to the anthropogenic activities like traffic, walking and playing activities in schools, hospitals, recreational areas and also the industrial pollution. Results revealed that air quality of Haripur city is at higher risk due to anthropogenic activities and from the industrial pollution caused by Hattar Industrial Estate. The concentration of PM detected in the air samples showed high concentration of PM in the ambient air of Haripur city as well. It was observed that elevated concentration of PM pollution was due to poor monitoring, management and law enforcement of the federal and local regulatory authorities in Haripur city, Pakistan. If the regulatory authorities such as Environmental Protection Agency, Health Department and Local Government monitor the PM pollutants in different settings of Haripur city, then a decrease can be possible in the pollution level. The remedies that can be taken to overcome the problem of air pollution such as PM are plantation of trees at the sites where there are higher levels of air pollutants and use of masks on personal protection basis along with implementation of pollution control system in industries of Hattar Industrial Estate Haripur city, Pakistan.

\section{References}

ABALI, H., ETEBU, O.M. and LETON, T.G., 2018. Seasonal particulate pollution in port Harcourt Nigeria. Journal of Environment Pollution and Human Health, vol. 6, pp. 20-25.

AKINFOLARIN, O.M., BOISA, N. and OBUNWO, C., 2017. Assessment of particulate matter-based air quality index in Port Harcourt, Nigeria. Journal of Environmental Analytical Chemistry, vol. 4, no. 4, pp. 1-4. http://dx.doi.org/10.4172/2380-2391.1000224.
ALAM, K., RAHMAN, N., KHAN, H.U., HAQ B.S. and RAHMAN, S., 2015. Particulate matter and its source apportionment in Peshawar, Northern Pakistan. Aerosol and Air Quality Research, vol. 15, no. 2, pp. 634-647. http://dx.doi.org/10.4209/aaqr.2014.10.0250.

ALI, Z., SHAHZADI, K., SIDRA, S., ZONA, Z., ZAINAB, I., AZIZ, K., AHMAD, M., RAZA, S.T., NASIR, Z.A. and COLBECK, I., 2015. Seasonal variation of particulate matter in the ambient conditions of Khanspur, Pakistan. Journal of Animal and Plant Sciences, vol. 25, no. 3, suppl. 2, pp. 700-705.

ARAÚJO, I.P., COSTA, D.B. and DE MORAES, R.J., 2014. Identification and characterization of particulate matter concentrations at construction jobsites. Sustainability, vol. 6, no. 11, pp. 76667688. http://dx.doi.org/10.3390/su6117666.

ASHRAF, D., KHANAM, S. and AHMAD, A., 2013. Effects of indoor air pollution on human health: a micro-level study of Aligarh City-India. Merit Research Journal of Education and Review, vol. 1, pp. 139-146.

AZIZ, K., ALI, Z., NASIR, Z.A. and COLBECK, I., 2015a. Assessment of airborne particulate matter (PM 2.5) in university classrooms of varrying occupancy. Journal of Animal and Plant Sciences, vol. 25, pp. 649-655.

BO, M., SALIZZONI, P., CLERICO, M. and BUCCOLIERI, R., 2017. Assessment of indoor-outdoor particulate matter air pollution: A review. Atmosphere, vol. 8, no. 12, pp. 136. http://dx.doi. org/10.3390/atmos8080136.

BORGHI, F., SPINAZZÈ, A., ROVELLI, S., CAMPAGNOLO, D., CATTANEO, A. and CAVALLO, D., 2017. Miniaturized monitors for assessment of exposure to air pollutants: A review. International Journal of Environmental Research and Public Health, vol. 14, no. 8, pp. 909. http://dx.doi.org/10.3390/ijerph14080909. PMid:28805684.

CESARONI, G., FORASTIERE, F., STAFOGGIA, M., ANDERSEN, Z.J., BADALONI, C., BEELEN, R., CARACCIOLO, B., DE FAIRE, U., ERBEL, R., ERIKSEN, K.T., FRATIGLIONI, L., GALASSI, C., HAMPEL, R., HEIER, M., HENNIG, F., HILDING, A., HOFFMANN, B., HOUTHUIJS, D., JÖCKEL, K.H., KOREK, M., LANKI, T., LEANDER, K., MAGNUSSON, P.K., MIGLIORE, E., OSTENSON, C.G., OVERVAD, K., PEDERSEN, N.L., J, J.P., PENELL, J., PERSHAGEN, G., PYKO, A., RAASCHOUNIELSEN, O., RANZI, A., RICCERI, F., SACERDOTE, C., SALOMAA, V., SWART, W., TURUNEN, A.W., VINEIS, P., WEINMAYR, G., WOLF, K., DE HOOGH, K., HOEK, G., BRUNEKREEF, B. and PETERS, A., 2014. Long term exposure to ambient air pollution and incidence of acute coronary events: prospective cohort study and meta-analysis in 11 European cohorts from the ESCAPE Project. BMJ (Clinical Research Ed.), vol. 348, no. jan21 3, pp. f7412. http://dx.doi.org/10.1136/bmj.f7412. PMid:24452269.

FISHBAIN, B., LERNER, U., CASTELL, N., COLE-HUNTER, T., POPOOLA, O., BRODAY, D.M., IÑIGUEZ, T.M., NIEUWENHUIJSEN, M., JOVASEVIC-STOJANOVIC, M., TOPALOVIC, D., JONES, R.L., GALEA, K.S., ETZION, Y., KIZEL, F., GOLUMBIC, Y.N., BARAM-TSABARI, A., YACOBI, T., DRAHLER, D., ROBINSON, J.A., KOCMAN, D., HORVAT, M., SVECOVA, V., ARPACI, A. and BARTONOVA, A., 2017. An evaluation tool kit of air quality micro-sensing units. The Science of the Total Environment, vol. 575, pp. 639-648. http:// dx.doi.org/10.1016/j.scitotenv.2016.09.061. PMid:27678046.

HABIL, M., MASSEY, D.D. and TANEJA, A., 2013. Exposure of children studying in schools of India to PM levels and metal contamination: sources and their identification. Air Quality, Atmosphere E Health, vol. 6, no. 3, pp. 575-587. http://dx.doi. org/10.1007/s11869-013-0201-3.

KHAN, M., GILANI, S. \& BHATTI, K., 2015. Polluted air quality component analysis from stack emission and its hazardous consequences on human health. Pakistan Journal of Meteorology, vol. 12, no. 23, pp. 13-24. 
MEHMOOD, T., ALI, Z., NOOR, N., SIDRA, S., NASIR, Z.A., \& COLBECK, I., 2015. Measurement of $\mathrm{NO}_{2}$ indoor and outdoor concentrations in selected public schools of lahore using passive sampler.Journal of Animal and Plant Sciences, vol. 25, no. 3, suppl. 2, pp. 681-686.

NAGAR, J.K., AKOLKAR, A. and KUMAR, R., 2014. A review on airborne particulate matter and its sources, chemical composition and impact on human respiratory system. International Journal of Environmental Sciences, vol. 5, pp. 447-463.

OSIMOBI, O., YORKOR, B. and NWANKWO, C., 2019. Evaluation of daily pollutant standard index and air quality index in a university campus in Nigeria using PM10 and PM2. 5 particulate matter. Journal of Science. Technology and Environment Informatics, vol. 7, no. 2, pp. 517-532. http://dx.doi.org/10.18801/ jstei.070219.54.

POKHREL, A.K., BATES, M.N., ACHARYA, J., VALENTINER-BRANTH, P., CHANDYO, R.K., SHRESTHA, P.S., RAUT, A.K. and SMITH, K.R., 2015. PM2. 5 in household kitchens of Bhaktapur, Nepal, using four different cooking fuels. Atmospheric Environment, vol. 113, pp. 159-168. http://dx.doi.org/10.1016/j.atmosenv.2015.04.060.

RAO, P.P. and REDDY, M.A., 2014. Baseline Air Quality Monitoring For Palvoncha Thermal Power Plant. International Journal of Engineering Research and Applications, vol. 4, pp. 22-30.

SARNAT, J.A., MARMUR, A., KLEIN, M., KIM, E., RUSSELL, A.G., SARNAT, S.E., MULHOLLAND, J.A., HOPKE, P.K. and TOLBERT, P.E., 2008. Fine particle sources and cardiorespiratory morbidity: an application of chemical mass balance and factor analytical source-apportionment methods. Environmental Health Perspectives, vol. 116, no. 4, pp. 459-466. http://dx.doi. org/10.1289/ehp.10873. PMid:18414627.

STAFOGGIA, M., CESARONI, G., PETERS, A., ANDERSEN, Z.J., BADALONI, C., BEELEN, R., CARACCIOLO, B., CYRYS, J., DE FAIRE, U., DE HOOGH, K., ERIKSEN, K.T., FRATIGLIONI, L., GALASSI,
C., GIGANTE, B., HAVULINNA, A.S., HENNIG, F., HILDING, A., HOEK, G., HOFFMANN, B., HOUTHUIJS, D., KOREK, M., LANKI, T., LEANDER, K., MAGNUSSON, P.K., MEISINGER, C., MIGLIORE, E., OVERVAD, K., OSTENSON, C.G., PEDERSEN, N.L., PEKKANEN, J., PENELL, J., PERSHAGEN, G., PUNDT, N., PYKO, A., RAASCHOUNIELSEN, O., RANZI, A., RICCERI, F., SACERDOTE, C., SWART, W.J., TURUNEN, A.W., VINEIS, P., WEIMAR, C., WEINMAYR, G., WOLF, K., BRUNEKREEF, B. and FORASTIERE, F., 2014. Long-term exposure to ambient air pollution and incidence of cerebrovascular events: results from 11 European cohorts within the ESCAPE project. Environmental Health Perspectives, vol. 122, no. 9, pp. 919-925. http://dx.doi.org/10.1289/ehp.1307301. PMid:24835336.

THURSTON, G.D., KIPEN, H., ANNESI-MAESANO, I., BALMES, J., BROOK, R.D., CROMAR, K., DE MATTEIS, S., FORASTIERE, F., FORSBERG, B., FRAMPTON, M.W., GRIGG, J., HEEDERIK, D., KELLY, F.J., KUENZLI, N., LAUMBACH, R., PETERS, A., RAJAGOPALAN, S.T., RICH, D., RITZ, B., SAMET, J.M., SANDSTROM, T., SIGSGAARD, T., SUNYER, J. and BRUNEKREEF, B., 2017. A joint ERS/ATS policy statement: what constitutes an adverse health effect of air pollution? An analytical framework. The European Respiratory Journal, vol. 49, no. 1, pp. 49. http://dx.doi. org/10.1183/13993003.00419-2016. PMid:28077473.

VALLENTE JUNIOR, J.R., ABUZO, A.A. and LARA, H.J.E., 2017. Evaluation of particulate matter concentrations in selected public elementary schools in Cagayan de Oro City, Philippines. Journal of the Eastern Asia Society for Transportation Studies, vol. 12, pp. 1023-1037.

WORLD HEALTH ORGANIZATION - WHO, 2015. Global tuberculosis report 2015. Geneva: WHO.

WU, W., JIN, Y. and CARLSTEN, C., 2018. Inflammatory health effects of indoor and outdoor particulate matter. The Journal of Allergy and Clinical Immunology, vol. 141, no. 3, pp. 833-844. http://dx.doi.org/10.1016/j.jaci.2017.12.981. PMid:29519450. 